\title{
Two new stygobiotic species of the genus Proasellus (Crustacea: Isopoda: Asellidae) from the North Caucasus
}

\author{
Dmitry M. Palatov ${ }^{1 *}$, Agniya M. Sokolova ${ }^{1,2}$
}

\author{
${ }^{1}$ A.N. Severtsov Institute of Ecology and Evolution of Russian Academy of Science, Leninsky Prt., \\ 33, Moscow119071 Russia.E-mail: triops@yandex.ru \\ ${ }^{2}$ N.K. Koltzov Institute of Developmental Biology of Russian Academy of Science, Vavilova str., 26, \\ Moscow, 119334, Russia.E-mail: enfado@yandex.ru \\ * Corresponding author \\ D.M. Palatov: ORCID: 0000-0002-8826-9316; ResearcherID: F-4766-2018 \\ A.M. Sokolova: ORCID: 0000-0002-2056-1310; ResearcherID: I-6778-2016
}

ABSTRACT. Two new stygobiotic species of the genus Proasellus Dudich, 1925 (Crustacea: Isopoda), P. uallagirus sp.n. and P. irystonicus sp.n., are described from ground waters of Alagyr Gorge (North Ossetia - Alania, Russia). These samples are the first Proasellus representatives found in the Terek River basin and in the North Caucasus. Both species are morphologically close to the Transcaucasian species, especially P. linearis (Birstein, 1967), but can be easily distinguished by several characters. $P$. uallagirus sp.n. differs in shape of pleopodes, size ratio of pleopod exopodites and endopodites, and arming of internal surface of the pereopod I propodus. P. irystonicus sp.n. also differs in arming of pereopods I-VII dactiluses. The two new species can be easily distinguished from each other by armature of pereopod I-VII dactiluses, body size, and some characters of pleopods, especially pleopodes II of males. They also had different ecological preferences: $P$. uallagirus sp.n. inhabits hyporhean streams and springs, while $P$. irystonicus sp.n. dwells in underground streams flowing through an abandoned mine.

How to site this article: Palatov D.M., Sokolova A.M. 2021. Two new stygobiotic species of the genus Proasellus (Crustacea: Isopoda: Asellidae) from the North Caucasus // Invert. Zool. Vol.18. No.4. P.481-501. doi: 10.15298/invertzool.18.4.05

KEY WORDS: Crustacea, Isopoda, Asellidae, Proasellus, new species, stygobiotns, North Caucasus, Ossetia.

\section{Два новых стигобионтных вида рода Proasellus Dudich, 1925 (Crustacea: Isopoda: Asellidae) с Северного Кавказа}

\author{
Дмитрий М. Палатов ${ }^{1 *}$, Агния М. Соколова ${ }^{1,2}$ \\ ${ }^{1}$ Институт экологии и эволючии им. А.Н. Севериова РАН, Ленинский просп., 33, Москва, \\ 119071 Poccuя. E-mail: triops@yandex.ru \\ ${ }^{2}$ Институт биологии развития им. Н.К. Кольцова, РАН, Вавилова, 26, Москва, 119334, \\ Россия.E-mail: enfado@yandex.ru \\ * Автор для переписки
}

РЕЗЮМЕ. Два новых вида стигобионтных водяных осликов рода Proasellus Dudich, 1925 (Crustacea: Isopoda), P. uallagirus sp.n. и P. irystonicus sp.n., описаны из грунтовых вод Алагирского ущелья на территории республики Северная Осетия-Алания. Представители этого рода впервые описываются с территории Северного Кавказа и 
из бассейна реки Терек. Оба вида морфологически достаточно близки к закавказским видам, особенно к P. linearis (Birstein, 1967), однако могут быть легко отличимы по ряду морфологических признаков. Так, P. uallagirus sp.n. отличается формой и соотношением размеров (длин) экзоподитов и эндоподитов плеоподов, вооружением внутренней поверхности проподуса переопода I. P. irystonicus sp.n. также отличается количеством члеников в жгутах антенн I и II, формой и соотношением размеров экзоподитов и эндоподитов плеоподов и, кроме того, вооружением дактилюсов переоподов I-VII. Новые виды легко отличаются между собой различным вооружением дактилюсов переоподов I-VII, размерами тела и рядом признаков плеоподов, особенно плеоподов II самца. Различны они и экологически: первый населяет подрусловые потоки и родники, второй - подземные ручьи, в том числе протекающие через заброшенные шахты.

Как цитировать эту статью: Palatov D.M., Sokolova A.M. 2021. Two new stygobiotic species of the genus Proasellus (Crustacea: Isopoda: Asellidae) from the North Caucasus // Invert. Zool. Vol.18. No.4. P.481-501. doi: 10.15298/invertzool.18.4.05

КЛЮЧЕВЫЕ СЛОВА: Crustacea, Isopoda, Asellidae, Proasellus, новый вид, стигобионты, Северный Кавказ, Осетия.

\section{Introduction}

Proasellus Dudich, 1925 (Crustacea: Isopoda) is one of the most speciose genera in the European groundwater, with approximately 120 species formally described to date (Capderrey et al., 2013). Moreover, recent molecular studies revealed a large number of unrecognized (morphologically cryptic) species of this genus (Morvan et al., 2013). However, Proasellus remains a fragmentary studied group within the west Palaearctic isopods. In Trancaucasia, for instance, only four species were described while the true diversity of this group was shown to be considerably higher (Turbanov et al., 2016; Golovatch et al., 2018; Palatov, Sokolova, 2019; Palatov, Chertoprud, 2020). All currently known Caucasian species of the genus Proasellus were described from the ground waters of the Black Sea coast by Ya.A. Birshtein. The only pigmented species among them, P. infirmus (Birstein, 1936), was found in the springs of the Gumista River valley (Sukhum Region, Abkhazia). Also three stigomorphic species were described from groundwaters of the Krasnodar Territory of Russia: P. linearis (Birstein, 1967) from a spring in Evstafevskaya Shchel near Gelendzhik, P. ljovuschkini (Birstein, 1967) from a karst vauclusian spring in the lower course of the Khosta River, and P. similis (Birstein, 1967) from a reservoir in Nikity Cave (basin of the Psakho River, a tributary of the Kudepsta River). In addition, several formally undescribed species of this genus are known from the Black Sea coast (Turbanov et al., 2016; Palatov, Chertoprud, 2020).

In general, stygobiotic fauna of the North Caucasus is still almost unknown. Only recently some data on Niphargus Schiødte, 1847 were published (Marin, Palatov, 2019, 2021). There is also report on a species of Proasellus found in Digor Gorge (Iraf District) of North Ossetia (Palatov, Chertoprud, 2020), but this taxon is still undescribed.

Here, we described two new species of the genus Proasellus from the Terek River basin, North Caucasus.

\section{Material and methods}

The samples were collected by a dip net in various subterranean and epigean water sources of the Ardon River valley on the northern slopes of the Great Caucasian Ridge (Republic of North Ossetia - Alania). Specimens were immediately fixed in $90 \%$ solution of ethanol. Photographs were made with a digital camera ToupCam 9.0 MP attached to a light microscope Olympus 
CX21. The scanning electron microscopy (SEM) images were made using Vega3 Tescan in the Paleontological Museum of the Paleontological Institute of the Russian Academy of Sciences, Moscow. The body length (bl., mm), i.e. the dorsal length from the anterior margin of head to the posterior margin of pleotelson without uropods and both antennas, was used as a standard measurement. The type material is deposited at the collection of Zoological Museum of Moscow State University, Moscow, Russia (ZMMU); other material is deposited in the personal authors' collection (PD).

New taxa were established based on the morphological species concepts. The morphological description was compiled using the most widely used terminology by Veronik et al. (2009).

\section{Results}

Representatives of the genus Proasellus were found in four sites within Iraf and Alagir districts of North Ossetia-Alania (Fig. 2). The first species, P. uallagirus sp.n., was found it two locations: a spring in the valley of the Ardon River, about $8 \mathrm{~km} \mathrm{~S}$ of Alagir town, $42^{\circ}$ $55^{\prime} 31.79^{\prime \prime} \mathrm{N}, 44^{\circ} 11^{\prime} 26.14^{\prime \prime} \mathrm{E}$ (Fig. 2A) and hyporhea of a spring in the Ardon River valley, two $\mathrm{km} \mathrm{S}$ of Alagir town, $42^{\circ} 59^{\prime} 49.44^{\prime \prime} \mathrm{N}, 44^{\circ}$ $13^{\prime} 08.53^{\prime \prime} \mathrm{E}$ (Fig. 2B). We failed to find any morphological differences between these two populations even though they dwell at opposite shores of the core river and the distance between them exceeds eight $\mathrm{km}$. The second species, $P$. irystonicus sp.n., inhabits a stream flowing through the abandoned mine in Sadon Gorge, $42^{\circ} 50^{\prime} 40.28^{\prime \prime} \mathrm{N}, 44^{\circ} 01^{\prime} 16.77^{\prime \prime} \mathrm{E}$ (Fig. 2C), where it reaches a high density on the decayed wooden sleepers. Morphologically, it is similar to the previously reported (Palatov, Chertoprud, 2020) specimens from springs of Digor Gorge, the Dargonkom River valley (Irafsky District), 42 $53^{\prime} 26^{\prime \prime} \mathrm{N}, 43^{\circ} 52^{\prime} 53^{\prime \prime} \mathrm{E}$ (Fig. 2D). But the material from there includes a single female only, so in the current work we avoid its description.

\section{Taxonomic account}

Order Isopoda Latreille, 1817

Suborder Asellota Latreille, 1802

Superfamily Aselloidea Latreille, 1802

Family Asellidae Rafinesque-Schmaltz, 1815

Genus Proasellus Dudich, 1925

\section{Proasellus uallagirus sp.n.}

Figs 1B, 3-5, 9A, C, E, G.

MATERIAL EXAMINED. Holotype $10^{7}$ (bl. $3.5 \mathrm{~mm}$ ), ZMMU Mc-1434, Russia, Republic of North Ossetia - Alania, Alagirsky District, a spring in the valley of the Ardon River, about $8 \mathrm{~km} \mathrm{~S}$ of Alagir town, $42^{\circ} 55^{\prime} 31.79^{\prime \prime} \mathrm{N}$, $44^{\circ} 11^{\prime} 26.14^{\prime \prime}$ E (Fig. 2A), 3 October 2020, coll. D. Palatov.

Paratypes. 1 ㅇ (bl. $4.2 \mathrm{~mm}$ ), ZMMU Mc1435; $10^{\top}$ (bl. $3.5 \mathrm{~mm}$ ), 2 우 (bl. 4.2 and 4.0 $\mathrm{mm})$, ZMMU Mc-1436 same locality and data as holotype.

Other materials: $3 \sigma^{7} \sigma^{\top}, 5+9$, PD 76Oset., same locality and data as holotype; $2 \sigma^{7} \sigma^{7}, 4$ 웅, PD 46Oset, Russia, Republic of North Ossetia Alania, Alagirsky District, a stream in the valley of the Ardon River, $2 \mathrm{~km} \mathrm{~S}$ of the Alagir town, $42^{\circ} 59^{\prime} 49.44^{\prime \prime} \mathrm{N}, 44^{\circ} 13^{\prime} 08.53^{\prime \prime} \mathrm{E}$ (Fig. 2B), 23 September 2020, coll. D. Palatov.

ETYMOLOGY. The species is named after the sub-region of Ossetia where it was found (Uallàgir = "Upper Ossetia" in Ossetian).

DIAGNOSIS. Small-sized, depigmented species. Antenna I with five to eight flagellar articles, flagellum of antenna II with 28-40 articles. Inner plate of maxillula with five apical pappose setae. Propodus I elongate, oval, its inferior margin without proximal apophysa, with one or two robust spiniform setae. Dactylus I with three or four short robust setae on inferior margin and five or six simple setae on superior margin. Dactylus of pereopods II-VII with a single robust stiff seta on inferior margin. Retinacula on medial margin of pleopod I with a single hook. Endopodite of pleopod II in males with weakly expressed basal apophysis, short distal apophysis and little goulot with devel- 


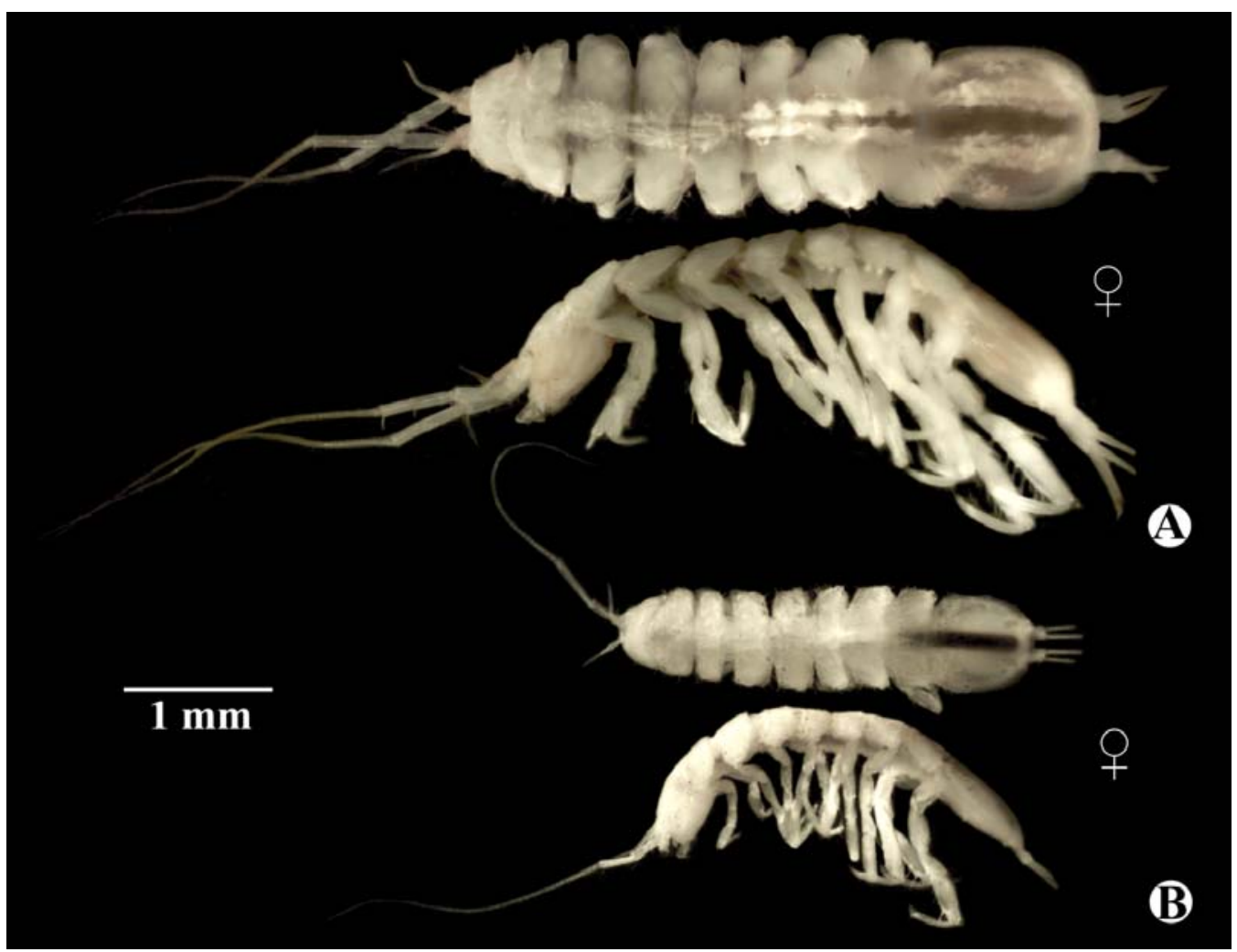

Fig. 1. Proasellus spp. from the Republic of North Ossetia - Alania, general view: A - Proasellus irystonicus sp.n., paratype ( $(+)$, a stream in an abandoned mine near the settlement of Sadon $\left(42^{\circ} 50^{\prime} 40.28^{\prime \prime} \mathrm{N}\right.$, $\left.44^{\circ} 01^{\prime} 16.77^{\prime \prime} \mathrm{E}\right)$; В - Proasellus uallagirus sp.n., паратип (+), a spring in the valley of the Ardon River $\left(42^{\circ} 55^{\prime} 31.79^{\prime \prime} \mathrm{N}, 44^{\circ} 11^{\prime} 26.14^{\prime \prime} \mathrm{E}\right)$.

Рис. 1. Proasellus spp. с территории республики Северная Осетия - Алания, общий вид: А Proasellus irystonicus sp.n., паратип (+), ручей в заброшенной шахте около поселка Садон $\left(42^{\circ} 50^{\prime} 40.28^{\prime \prime} \mathrm{N}, 44^{\circ} 01^{\prime} 16.77^{\prime \prime} \mathrm{E}\right)$; В - Proasellus uallagirus sp.n., паратип (+), родник в долине реки Ардон $\left(42^{\circ} 55^{\prime} 31.79^{\prime \prime} \mathrm{N}, 44^{\circ} 11^{\prime} 26.14^{\prime \prime} \mathrm{E}\right)$.

oped lips. Endopodite of pleopod II in females subtriangular, with three short marginal simple setae. Lateral and terminal margins of pleopod III with 10-11 short simple setae, its endopodites about 1.6 times shorter than exopodites. Lateral margin of exopodite of pleopod IV without setae. Endopodite of pleopods IV suboval, about 1.3 times shorter than exopodite. Exopodite of pleopods V ovoid, elongated, 2.2 times as long as wide, lateral margins without setae. Endopodite suboval, its length constitutes $90 \%$ of exopodite length. Uropods similar in males and

$44^{\circ} 01^{\prime} 16.77^{\prime \prime} \mathrm{E}$ (type locality of Proasellus irystonicus sp.n.); D - a spring in the valley of the Dargonkom River, 42 $53^{\prime} 26^{\prime \prime} \mathrm{N}, 43^{\circ} 52^{\prime} 53^{\prime \prime} \mathrm{E}$ (Proasellus sp., after Palatov, Chertoprud, 2020).

Рис. 2. Карта мест сбора видов рода Proasellus на территории республики Северная Осетия - Алания и природные местообитания описываемых видов: А - родник в долине реки Ардон, в 8 км южнее

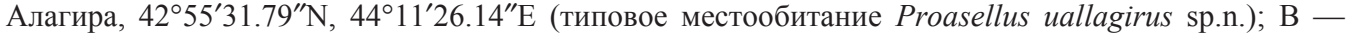
ручей в долине реки Ардон, 2 км южнее Алагира, 42 $59^{\prime} 49.44^{\prime \prime} \mathrm{N}, 44^{\circ} 13^{\prime} 08.53^{\prime \prime} \mathrm{E}$ (второе местообитание Proasellus uallagirus sp.n.); С - ручей в заброшенной шахте близ поселка Садон, $42^{\circ} 50^{\prime} 40.28^{\prime \prime} \mathrm{N}$, $44^{\circ} 01^{\prime} 16.77^{\prime \prime}$ (типовое местообитание Proasellus irystonicus sp.n.), D - родник в долине реки Даргонком, 42 $53^{\prime} 26^{\prime \prime} \mathrm{N}, 43^{\circ} 52^{\prime} 53^{\prime \prime} \mathrm{E}$ (Proasellus sp. по Palatov, Chertoprud, 2020). 

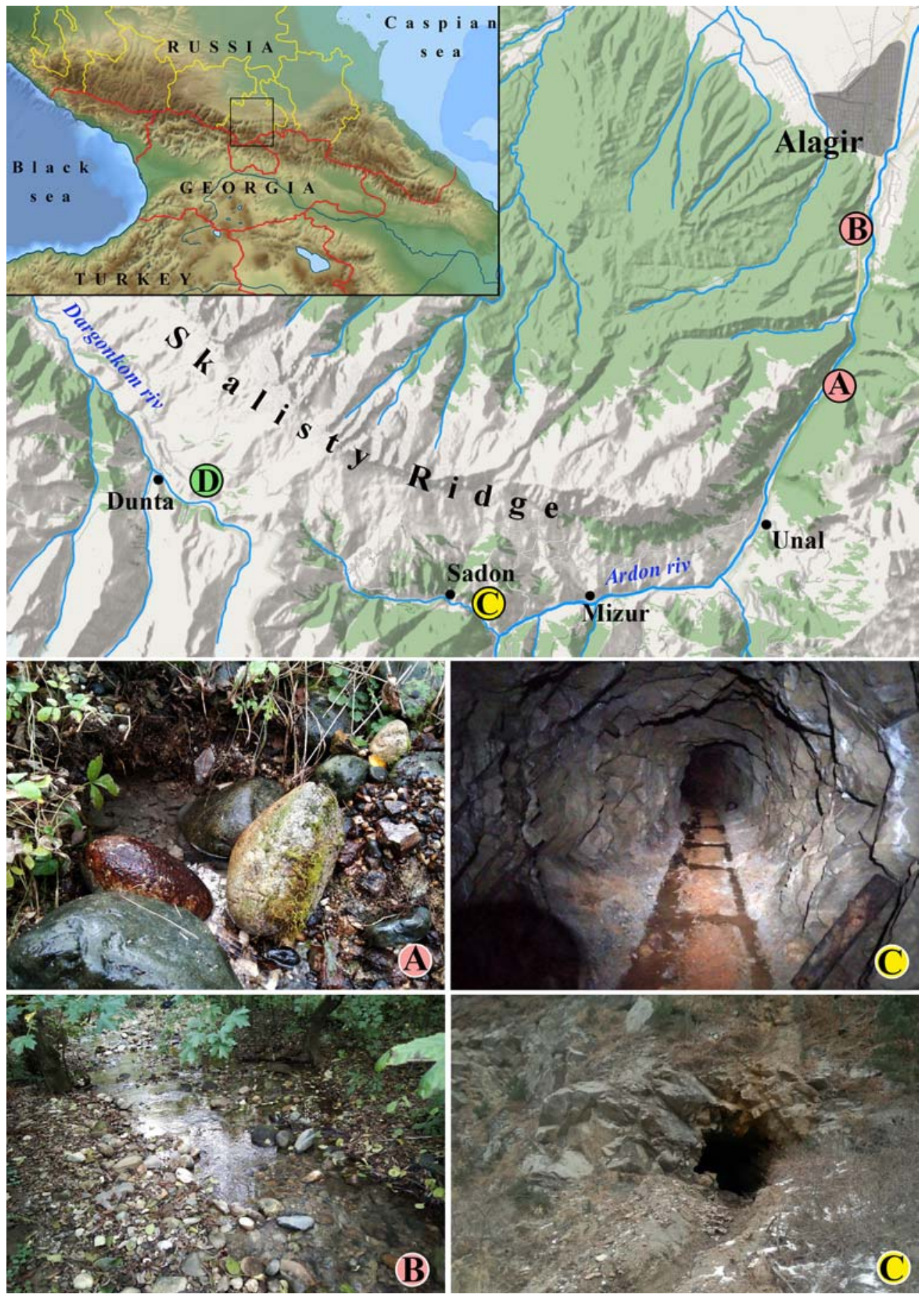

Fig. 2. Map of collection sites for the species of the genus Proasellus in the Republic of North Ossetia Alania and natural habitet of described species: A - a spring in the valley of the Ardon River, $8 \mathrm{~km} \mathrm{~S}$ of the Alagir town, $42^{\circ} 55^{\prime} 31.79^{\prime \prime} \mathrm{N}, 44^{\circ} 11^{\prime} 26.14^{\prime \prime} \mathrm{E}$ (type locality of Proasellus uallagirus sp.n.); B - a stream in the valley of the Ardon River, $2 \mathrm{~km} \mathrm{~S}$ of the Alagir town, $42^{\circ} 59^{\prime} 49.44^{\prime \prime} \mathrm{N}, 44^{\circ} 13^{\prime} 08.53^{\prime \prime} \mathrm{E}$ (second habitet Proasellus uallagirus sp.n.); C - a stream in an abandoned mine near the Sadon settlement, $42^{\circ} 50^{\prime} 40.28^{\prime \prime} \mathrm{N}$, 


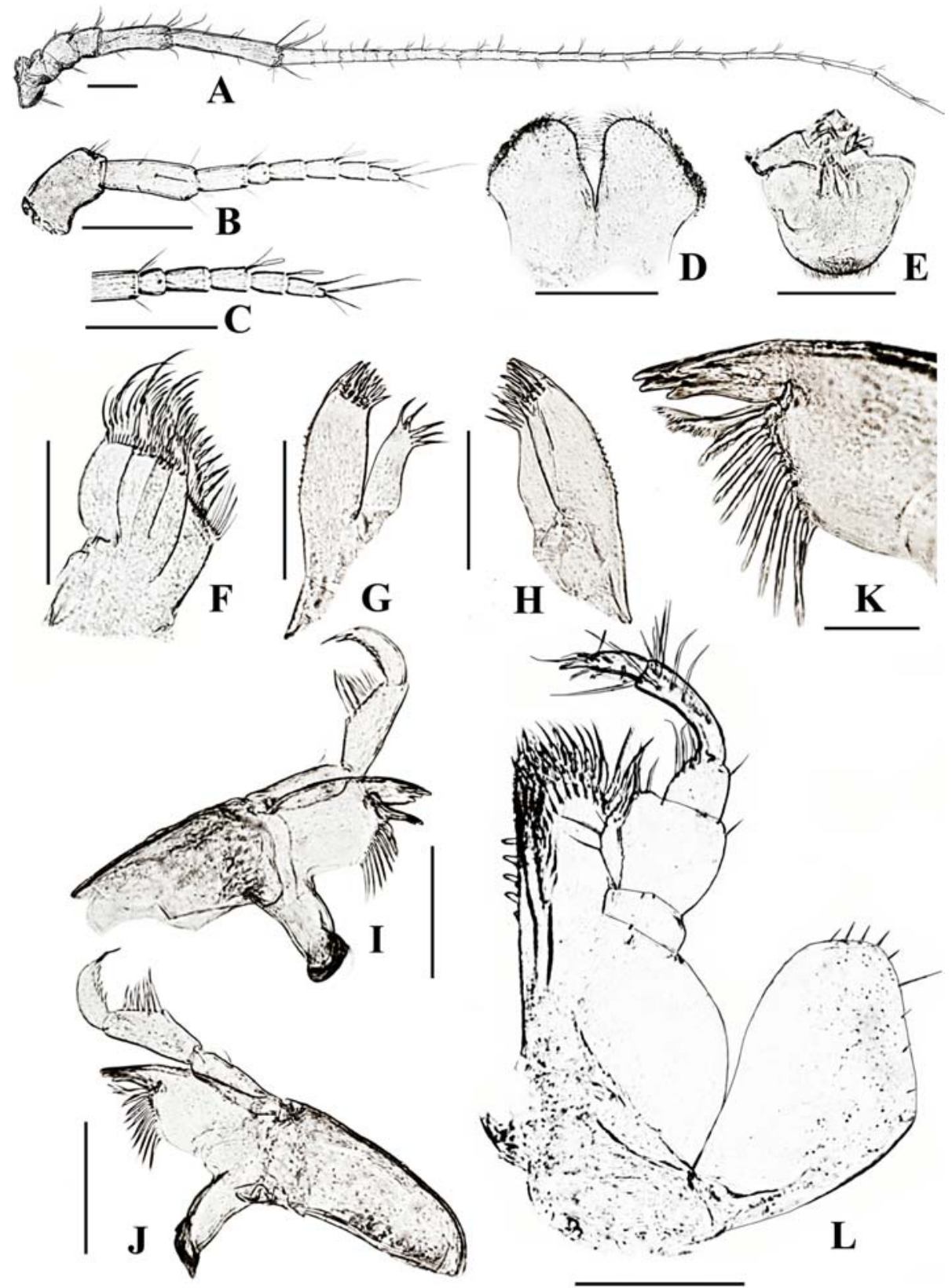

Fig. 3. Proasellus uallagirus sp.n. Holotype $\left(\mathrm{O}^{7}\right)$ from a spring in the valley of the Ardon River, $8 \mathrm{~km} \mathrm{~S}$ of the Alagir town: A — antenna II; B — antenna I; C — flagellum of antenna I; D - labium; E - labrum; $\mathrm{F}$ - maxilla; $\mathrm{G}$ - left maxillula; $\mathrm{H}$ — right maxillula; I — left mandible; $\mathrm{J}$ - right mandible; $\mathrm{K}$ — pars incisiva (incisor) of right mandible; $\mathrm{L}-$ maxilliped. Scale bars: A-J, L $-0.2 \mathrm{~mm} ; \mathrm{K}-0.025 \mathrm{~mm}$.

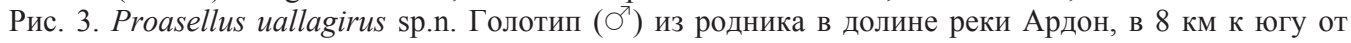
Алагира: А — антенна II; В - антенна I; C — жгутик антенны I; D — лабиум (нижняя губа); Е лабрум (верхняя губа); F - максилла; $\mathrm{G}$ - левая максиллула; H - правая максиллула; I — левая мандибула; J - правая мандибула; $\mathrm{K}$ - резец (инцизор) правой мандибулы; L — максиллипед. Масштабная линейка: A-J, L - 0,2 мм; K-0,025 мм. 


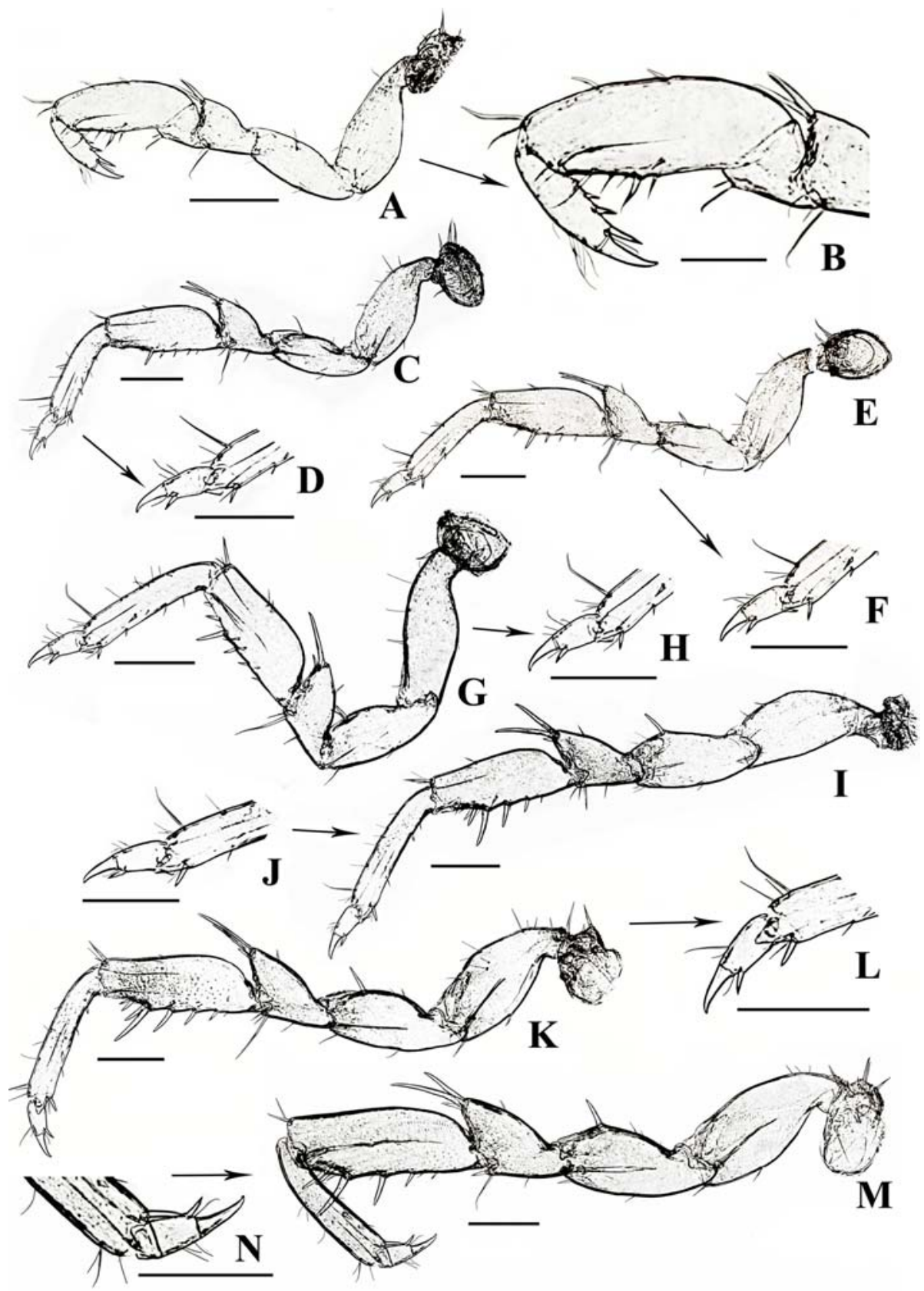

Fig. 4. Proasellus uallagirus sp.n. Holotype $\left(\mathrm{O}^{\top}\right)$ from a stream in an abandoned mine near the settlement of Sadon: A - pereopod I; B - dactylus of PI; C - pereopod II; D - dactylus of PII; E - pereopod III; F - dactylus of PIII; G - pereopod IV; H - dactylus of PIV; I - pereopod V; J - dactylus of PV; K pereopod VI; L - dactylus of PVI; M - pereopod VII; N — dactylus of PVII. Scale bars: $0.2 \mathrm{~mm}$.

Рис. 4. Proasellus uallagirus sp.n. Голотип $\left(\sigma^{7}\right)$ из ручья в заброшенной шахте близ поселка Садон: А - переопод I; В - дактилус переопода I; C - переопод II; D - дактилус переопода II; E переопод III; F - дактилус переопода III; G - переопод IV; H - дактилус переопода IV; I переопод V; J — дактилус переопода V; K — переопод VI; L — дактилус переопода VI; M — переопод VII; N — дактилус переопода VII. Масштабная линейка: 0,2 мм. 


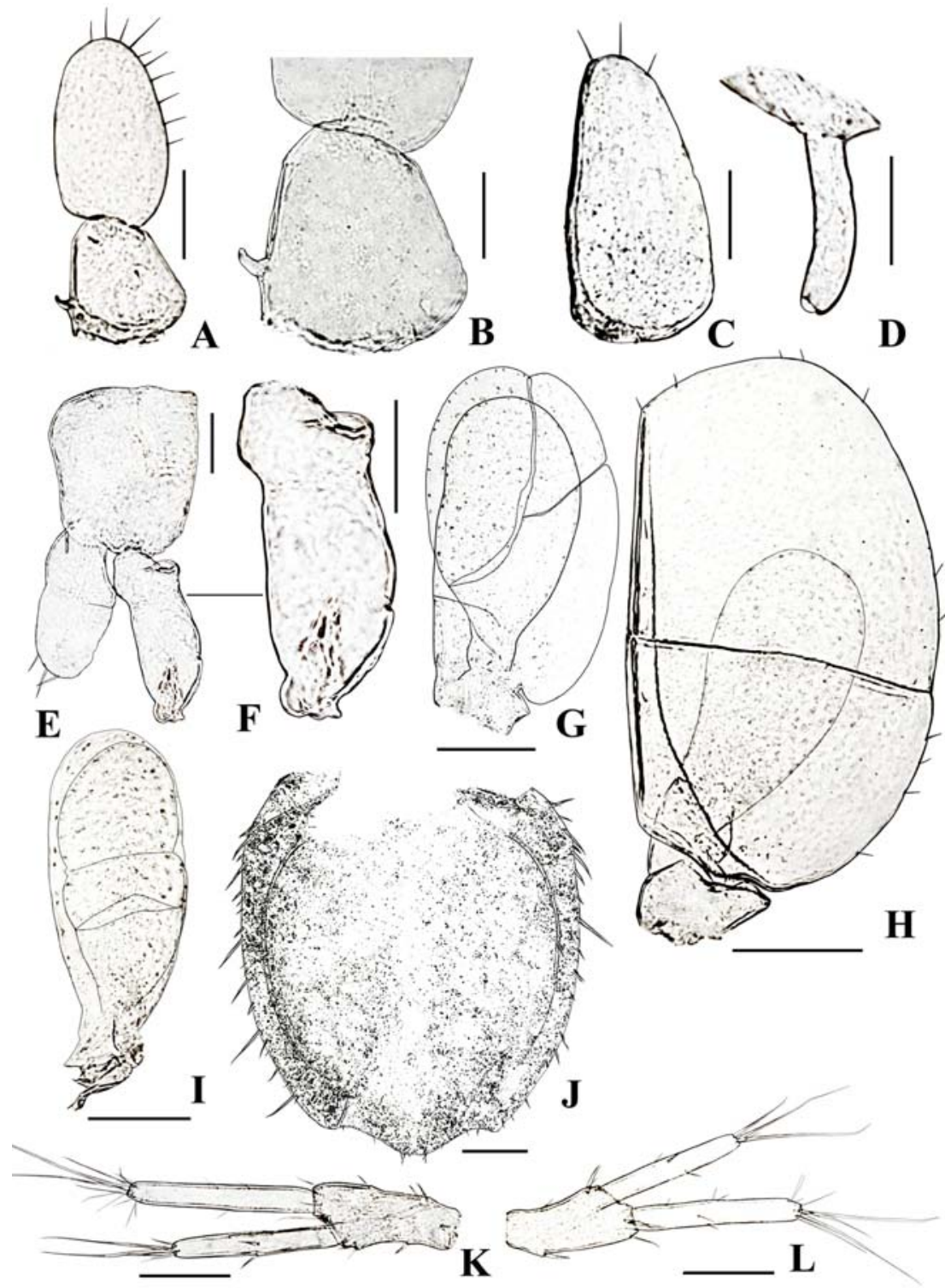

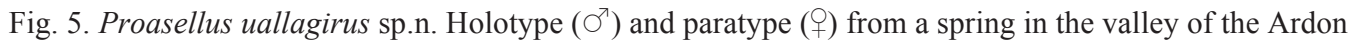
River, $8 \mathrm{~km} \mathrm{~S}$ of the Alagir town: A — pleopod I ( $\sigma^{7}$ holotype); B - retinacula on medial margin of pleopod I protopodite; $\mathrm{C}$ - pleopod II ( + paratype); D — genital papilla ( $\bigcirc^{\top}$ holotype); E — pleopod II ( $\bigcirc^{7}$ holotype); $\mathrm{F}$ - endopodite of pleopod II ( $\sigma^{7}$ holotype); $\mathrm{G}$ - pleopod IV ( $\mathrm{O}^{7}$ holotype); H - pleopod III ( $\sigma^{7}$ holotype); I - pleopod V ( $\sigma^{7}$ holotype); J - pleotelson ( $\sigma^{7}$ holotype); K — uropod ( $\sigma^{7}$ holotype); L — uropod ( paratype). Scale bars: A, C-E, G-I - $0.1 \mathrm{~mm}$; J-L $-0.1 \mathrm{~mm}$; B, F $-0.025 \mathrm{~mm}$.

Рис. 5. Proasellus uallagirus sp.n. Голотип (О7) и паратип (+) из родника в долине реки Ардон, в 8 км к югу от Алагира: А - плеопод I (голотип $\left.0^{7}\right)$; В - ретинакула на медиальной поверхности

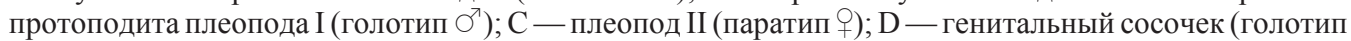
$\left.\mathrm{O}^{7}\right) ; \mathrm{E}$ - плеопод II (голотип $\left.\mathrm{O}^{7}\right) ; \mathrm{F}$ - эндоподит плеопода II (голотип О $\left.\mathrm{O}^{7}\right) ; \mathrm{G}$ - плеопод IV (голотип $\left.\mathrm{O}^{7}\right) ; \mathrm{H}$ - плеопод III (голотип О7); I — плеопод V (голотип О уропод (голотип $\left.\mathrm{O}^{7}\right) ; \mathrm{L}-$ уропод (паратип +). Масштабная линейка: A, C-E, G-I - 0,1 мм; J-L 0,1 мм; B, F-0,025 мм. 
females, proto-, endo- and exopodite length relation is $1: 1.2: 1.3$, respectively.

DESCRIPTION. Stygobiont, blind and depigmented.

Body about four times as long as wide (Fig. 1B), slim, elongated.

Head (Fig. 9A) with frontal margin bisinuate, medially concave, without rostral process, lateral margins straight, each with small posterolateral protuberance, with several short stiff setae. Pigmented spots absent.

Pereonites (Fig. 9E) depigmented, anterolateral, lateral and posterolateral margins fringed with long and short spiniform setae. Coxopods well developed, margins of all epimerae dorsally visible.

Pleomere I-II small (Fig. 9G), their width constitutes only $33 \%$ of pereonite VII width, forming a stalk largely covered by posterior margin of pereonite VII. Pleotelson (Figs 5J; 9G) rounded, suboval or subrectangular, with length 1.0-1.1 times of its width, terminal edge bisinuate with obtusely triangular median prominence (Fig. 5J). Lateral margins with few (four to seven) long spiniform setae, approximately two or three shorter setae placed between two longer ones. Terminal edge with numerous short setae, subterminal margin with scarce short setae. Dorsal surface covered with numerous short delicate setae (Fig. 9G).

Antenna I (Fig. 3B, C) length $12 \%$ of body length, with three peduncular articles. First article robust, with straight superior (longer) and curved inferior (shorter) margin, other two articles cylindrical. First and second article subequal in length, third article 1.9 times shorter than each of them. Longest setae on articles I and II with length 0.5 of articles length. Flagellum (Fig. 3C) of five (in holotype) or five to eight (in paratypes) articles, usually with three or four articles bearing one aesthetasc. Proximal aesthetascs mainly as long as their parallel articles.

Antenna II (Fig. 3A) length $87 \%$ of body length, with six peduncular and 31 flagellar articles (in holotype) or 28-40 flagellar articles (in paratypes). Sixth peduncular article 1.6 times as long as fifth, both with long and short setae on superior margins. Flagellum length $70 \%$ of antenna II length.

Labrum (Fig. 3E) trapezoidal, with fine simple setae at rounded apex, epistome tapering, with fine setae along margin.

Labium (Fig. 3D) wide, subquadrate, divided almost to half of length.

Mandibulae robust (Fig. 3I, J, K): Pars molaris (molar process) U-shaped, with toothed margin and wrinkled crushing surface. Pars incisiva (incisor) formed by four blunt cusps arranged in semi-circle (Fig. 3K). Left lacinia mobilis with five cusps, spine row of 16 biserrate setae (Fig. 3I), right mandible without lacinia mobilis (Fig. 3J). Palp of three articles. First and second article of subequal length. First article narrow, with one or two simple setae on extero-subapical margin. Second article with two simple setae and about 15-16 robust long and short biserrate setae along external margin. Third article length 0.7 times of second, with row of about 15 robust biserrate setae along external margin.

Maxillulae of equal shape and size (Fig. 3G, $\mathrm{H})$ with inner plate with five apical pappose setae; outer plate with 13 dentate robust setae and a single simple seta situated subapically on lateral margin.

Maxilla (Fig. 3F) with inner plate longer than outer plate, rounded sub-triangular, with longer row of 16-20 serrate robust setae, shorter row of five or six bifid setae situated laterally and apically, and with oblique row of 30 simple setae; lateral and middle plates with 23 and 13 striated setae, respectively.

Maxilliped (Fig. 3L) endite distal margin bearing about 16 biserrate robust setae and long simple setae. Mesial margin with about 17-20 biserrate setae, distomesial margin with setulose fringe and four to six coupling hooks, lateral margin with dense setulose fringe. Palp has five articles. First article short, with a single short seta situated apically on inner margin, second about 2.4 times as long as first, subtrapezoidal, with row of about 15 long medially directed simple setae on inner margin and two or three short setae on outer margin. Third article length $65-70 \%$ of second article length, less 
broad, with two short setae on outer margin and row of about six to eight setae on inner margin. Fourth article 2.1 times as long as third, slender, with row of three orfour and about 13-14 slender setae along outer and inner margin, respectively. Fifth article length $50 \%$ of fourth article length, ovoid, fringed with 13 slender setae, with a single stiff simple apical seta. Epipodite subrectangular, lateral margin fringed with about nine to eleven short setae.

With exception of first pair, seven pairs of pereopods ambulatory and similar in structure, increasing in length towards posterior pairs.

Pereopod I (Figs 4A, B; 9C) with short oval articles, its length $25 \%$ of body length, length relation of articles from basis (article I) to dactylus (article VII): $1: 0.70: 0.44: 0.22: 0.90$ : 0.67 , unguis length $45 \%$ of dactylus length. Propodus I elongate, oval, up to 2.8 times as long as wide, inferior margin without proximal apophysa, straight or weakly convex, armed with 1-2 robust spiniform setae. Mesial surface with a two-three short simple setae. Dactylus I (Figs 4B; 9C) about 1.4 times as long as propodus, with three or four short robust setae on inferior margin and five or six simple setae on superior margin.

Pereopod II (Fig. 4C, D) with long slender articles, its length $29 \%$ of body length, length relation of articles from basis to dactylus: 1 : $0.84: 0.53: 1.01: 0.82: 0.42$, unguis length $42 \%$ of dactylus length. Carpus II inferior margin with row of 5 robust setae. Propodus II inferior margin with row of three or four simple setae, mesial surface with one or two simple setae, inferodistal corner with a single stiff acute robust seta, superior margin and submarginal surface with six to eight simple setae. Dactylus II (Fig. 4D) inferior margin with a single robust stiff seta, superior margin distally with three simple setae.

Pereopod III (Fig. 4E, F) with long slender articles, its length $31 \%$ of body length, length relations of articles from basis to dactylus: 1.0 : $0.79: 0.57: 1.07: 1.00: 0.46$, unguis length $42 \%$ of dactylus length. Carpus III inferior margin with row of five robust setae. Propodus III inferior margin with row of three or four simple setae, mesial surface with one or two simple setae, inferodistal corner with a single stiff acute robust seta, superior margin and submarginal surface with six or seven simple setae. Dactylus III (Fig. 4F) inferior margin with a single robust stiff seta, superior margin with four simple distal setae.

Pereopod IV (Fig. 4G, H) with long slender articles, its length $35 \%$ of body length, length relation of articles from basis to dactylus: 1 : $0.78: 0.46: 0.93: 0.98: 0.42$, unguis length $43 \%$ of dactylus length. Carpus IV inferior margin with row of six robust setae, mesial surface with two or three short robust setae. Propodus IV inferior margin with row of three or four simple setae, mesial surface with one or two simple or robust setae, inferodistal corner with a single stiff acute robust seta, superior margin and submarginal surface with eight to ten simple setae. Dactylus IV (Fig. 4H) inferior margin with a single robust stiff seta, superior margin distally with four simple setae.

Pereopod V (Fig. 4I, J) with long slender articles, its length $44 \%$ of body length, length relation of articles from basis to dactylus: 1 : $0.94: 0.60: 1.12: 1.13: 0.44$, unguis length $44 \%$ of dactylus length. Carpus V inferior margin with row of five robust setae, mesial surface with two short robust setae. Propodus V inferior margin with row of three simple or robust setae, mesial surface with one or two simple setae, inferodistal corner with a single stiff acute robust seta, superior margin and submarginal surface with seven or eight simple setae. Dactylus $\mathrm{V}$ (Fig. 4J) inferior margin with a single robust stiff seta, superior margin distally with three simple setae.

Pereopod VI (Fig. 4K, L) with long slender articles, its length $46 \%$ of body length, length relation of articles from basis to dactylus: 1 : $0.88: 0.56: 1.02: 1.00: 0.40$, unguis length $42 \%$ of dactylus length. Carpus VI inferior margin with row of seven or eight robust setae, mesial surface with one or two short simple setae. Propodus VI inferior margin with row of three simple or robust setae, mesial surface with one or two simple setae, inferodistal corner with a single stiff acute robust seta, superior margin 
and submarginal surface with seven or eight simple setae. Dactylus VI (Fig. 4L) inferior margin with a single robust stiff seta, superior margin distally with three simple setae.

Pereopod VII (Fig. 4M, N) with long slender articles, its length $53 \%$ of body length, length relations of articles from basis to dactylus: 1 : $0.86: 0.59: 1.18: 0.93: 0.37$, unguis length $46 \%$ of dactylus length. Carpus VII inferior margin with row of six or seven robust and two or three simple setae, mesial surface without setae. Propodus VII inferior margin with row of three simple or robust setae, mesial surface with two or three short robust setae, inferodistal corner with a single stiff acute robust seta, superior margin and submarginal surface with six or seven simple setae. Dactylus VII (Fig. $4 \mathrm{~N}$ ) inferior margin with a single robust stiff seta, superior margin distally with three simple setae.

Genital papillae (Fig. 5D) is thin, cylindrical, slightly curved.

Pleopod I (Fig. 5A, B) with protopodite subtrapezoidal, 1.12 times as long as wide, retinacula on medial margin of a single hook (Fig. 5B). Exopodite elongated ovoid, its width $60 \%$ of its length, with 10 simple setae on lateral margin, without concavity on lateral margin.

Pleopod II (Fig. 5E, F) with protopodite subrectangular, its width $86 \%$ of its length. Anterolateral corner with a single simple seta. Exopodite suboval, elongated, two times as long as wide. Distal article rounded, with three short distal simple setae. Proximal segment of exopodite without setae. Endopodite elongated, its width $35 \%$ of its length, subequal of protopodite in length, with weakly expressed basal apophysis, short distal apophysis and little goulot with developed lips (Fig. 5F).

Pleopod II of female (Fig. 5C) subtriangular, about two times as long as wide, with three short marginal simple setae.

Pleopod III (Fig. 5H) with exopodite suboval, about 1.7 times as long as wide, with almost straight medial margin. Lateral and terminal margins with 10-11 short simple setae. Endopodite about 1.6 times shorter than exopodite.
Pleopod IV (Fig. 5G) with exopodite broadly ovoid, about 1.74 times as long as wide, lateral margins without setae. Linea transversalis very well defined, linea conjungens clearly defined along entire length. Endopodite suboval, about 1.3 times shorter than exopodite.

Pleopod V (Fig. 5I) with exopodite ovoid, elongated, 2.2 times as long as wide, lateral margins without setae. Distal margin rounded. Endopodite suboval, its length $90 \%$ of exopodite length.

Uropods (Fig. 5K, L) similar in males and females, as long as $50-52 \%$ of pleotelson. Proto-, endo- and exopodite length relations: 1 : $1.17: 1.33$, respectively. Basis with two or three stout spiniform setae on inner and outer margins each and with distal group of three or four simple setae. Exopodite with one to three short simple setae on inner and outer margins each and with terminal group of long simple setae, longest seta length $85 \%$ of exopodite length. Endopodite with two or three short spiniform or simple setae on inner and outer margins each and with terminal group of long simple setae, longest seta length $78 \%$ of exopodite length.

BODY SIZE. The largest collected female had bl. $4.2 \mathrm{~mm}$; the largest male had bl. $3.5 \mathrm{~mm}$.

TAXONOMIC REMARKS. The species can be most easily separated from Proasellus infirmus, by the following features: 1) a single coupling hook in retinacula of pleopod I (vs two hooks, see Birstein, 1936, fig. 7); 2) lack of eyes, white depigmented body (vs eyes frothree facets, pigmented body, "brighter than Asellus aquaticus", see Birstein, 1936, p. 237 and Birstein, 1951, p. 85 and fig. 112); 3) lack of long plumose setae on pleopode II (vs setae on pleopode II plumose, long, exceed half of their length, see Birstein, 1936, figs 8, 9).

The species can be most easily separated from $P$. linearis, by: 1) significantly larger endopodites of pleopodes III-V, exopodite/endopodite ratio of pleopodes III-V is 1.6, 1.3, 1.1 vs 3.0, 1.9, 1.4, respectively (see Birstein, 1967, fig. 1); 2) armature of inferior margin of propodus of pereopod I comprises a single stout spiniform seta (vs three spiniform setae, see Birstein, 1967, fig. 1). 
The species can be easily separated from $P$. ljovuschkini, by: 1) a single coupling hook in retinacula of pleopod I (vs two hooks, see Birstein, 1967, fig. 2); 2) lack of a setae on mesial margin of pleopodes III and pleopodes II in female (vs prominent setae, see Birstein, 1967, fig. 2).

The species can be easily separated from $P$. similis, by: 1) a single coupling hook in retinacula of pleopod I (vs two hooks, see Birstein, 1967, fig. 3); 2) rami of uropod almost parallel (vs arranged at the angle of almost $80^{\circ}$, see Birstein, 1967, fig. 3); 3) pleopod IV wide, its exopodite about 1.62 times as long as wide, without a lateral seta (vs pleopod IV narrow, its exopodite about 2.20 times as long as wide, with a lateral seta, see Birstein, 1967, fig. 3).

For the differences from P. irystonicus sp.n. see below.

DISTRIBUTION AND ECOLOGY. Currently known as strictly distributed endemic species from several closely located springs on the valley of the Ardon River $\left(42^{\circ} 50^{\prime} 40.28^{\prime \prime} \mathrm{N}\right.$, $44^{\circ} 01^{\prime} 16.77^{\prime \prime} \mathrm{E}$ and $42^{\circ} 59^{\prime} 49.44^{\prime \prime} \mathrm{N}, 44^{\circ} 13^{\prime}$ $\left.08.53^{\prime \prime} \mathrm{E}\right)$. The species was found together with the following spring-dwelling invertebrates: Gammarus cf. pulex (Linnaeus, 1758) (Amphipoda: Gammaridae), Niphargus sp. (Amphipoda: Niphargidae), Nemoura sp. (Plecoptera: Nemouridae), Plectrocnemia latissima Martynov, 1913 (Trichoptera: Polycentropodidae) and Agabus guttatus (Paykull, 1798) (Coleoptera: Dytiscidae).

\section{Proasellus irystonicus sp.n.}

Figs 1A, 6-8, 9B, D, F, H.

MATERIAL EXAMINED. Holotype $10^{7}$ (bl. $5.8 \mathrm{~mm}$ ), ZMMU Mc-1431, Russia, Republic of North Ossetia - Alania, Alagirsky District, a stream in an abandoned mine near the settlement of Sadon, $42^{\circ} 50^{\prime} 40.28^{\prime \prime} \mathrm{N}, 44^{\circ} 01^{\prime}$ 16.77"E (Fig. 2C), 8 October 2020, coll. D. Palatov.

Paratypes. 19 (bl. $6.5 \mathrm{~mm}$ ), ZMMU Mc1432; $10^{7}$ (bl. $5.5 \mathrm{~mm}$ ), 2 \% (bl. 6.5 and 6.0 $\mathrm{mm}$ ), ZMMU Mc-1433, same locality and data as holotype.
Other materials: $8 \sigma^{\top} \sigma^{7}, 1690$, PD 85 Oset., same locality and date as holotype.

ETYMOLOGY. The name derived from the endonym of Ossetia (Iryston).

DIAGNOSIS. Medium sized, depigmented species. Antenna I with eight to twelve flagellar articles, flagellum of antenna II with 36-54 flagellar articles. Inner plate of maxillula with five apical pappose setae. Propodus I elongate, oval, its inferior margin without proximal apophysa, with three robust spiniform setae. Dactylus I with six short robust setae on inferior margin and six simple setae on superior margin. Dactylus of pereopods II-VII with two robust stiff setae on inferior margin. Retinacula on medial margin of pleopod I with a single hook. Endopodite of pleopod II in males with distinct basal apophysis, elongated distal apophysis and with weakly expressed goulot without lips. Endopodite of pleopod II in females subtriangular, with seven short marginal simple setae. Lateral and terminal margins of pleopods III with 1112 short simple setae, their endopodite about 1.7 times shorter than exopodite. Lateral margin of exopodite of pleopods IV without setae. Endopodite of pleopods IV suboval, about 1.1 times shorter than exopodite. Exopodite of pleopods V ovoid, elongated, two times as long as wide, lateral margins without setae. Endopodite suboval, its length $94 \%$ of exopodite length. Uropods different in males and females, proto-, endo- and exopodite length relation is $1: 1.0$ : 1.1 in males and $1: 1.1: 1.2$ in females.

DESCRIPTION. Stygobiont, blind and depigmented.

Body elongated, about 3.6 times as long as wide (Fig. 1A).

Head (Fig. 9B) with frontal margin bisinuate, medially concave, without rostral process, lateral margins straight, each with small posterolateral protuberance, with several short stiff setae. Pigmented spots absent.

Pereonites (Fig. 9F) depigmented, anterolateral, lateral and posterolateral margins fringed with long and short spiniform setae. Coxopods well developed, margins of all epimerae dorsally visible.

Pleomere I-II small (Fig. 9H), its width only $25 \%$ of pereonite VII width, forming a stalk 


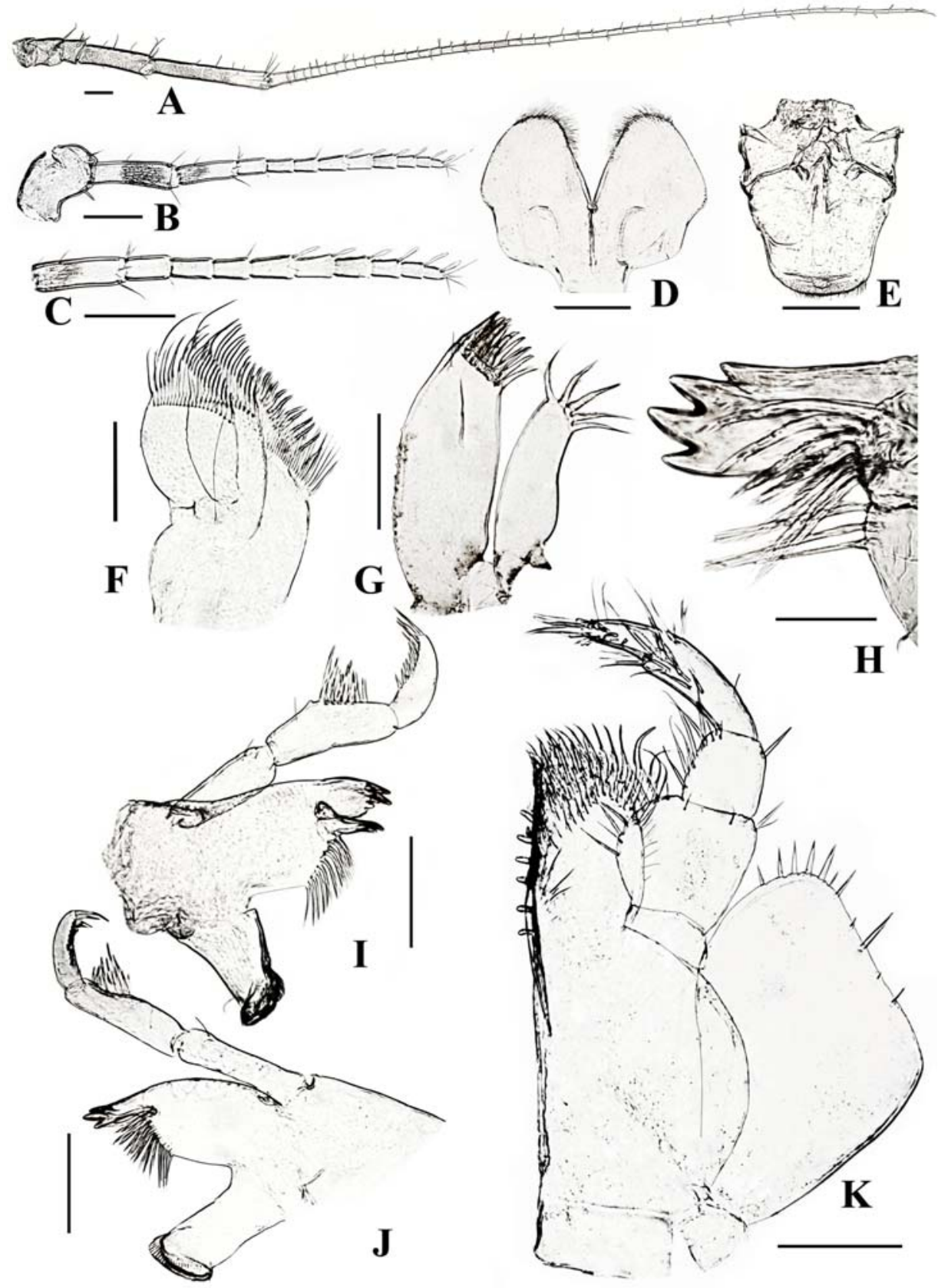

Fig. 6. Proasellus irystonicus sp.n. Holotype $\left(\mathrm{O}^{\top}\right)$ from a stream in an abandoned mine near the settlement of Sadon: A - antenna II; B - antenna I; C - flagellum of antenna I; D - labium; E - labrum; F maxilla; $\mathrm{G}$ - maxillula; $\mathrm{H}$ - pars incisiva (incisor) of right mandible; I — left mandible; $\mathrm{J}$ - right mandible; $\mathrm{K}-$ maxilliped. Scale bars: A-G, I-K $-0.2 \mathrm{~mm}$; H $-0.025 \mathrm{~mm}$.

Pис. 6. Proasellus irystonicus sp.n. Голотип ( $\left(^{7}\right)$ из ручья в заброшенной шахте близ поселка Садон: А антенна II; В — антенна I; C — жгутик антенны I; D — лабиум (нижняя губа); Е — лабрум (верхняя губа); F - максилла; G - максиллула; H - резец (инцизор) правой мандибулы; I — левая мандибула; J правая мандибула; $\mathrm{K}-$ максиллипед. Масштабная линейка: A-G, I-K - 0,2 мм; $\mathrm{H}-0,025$ мм. 


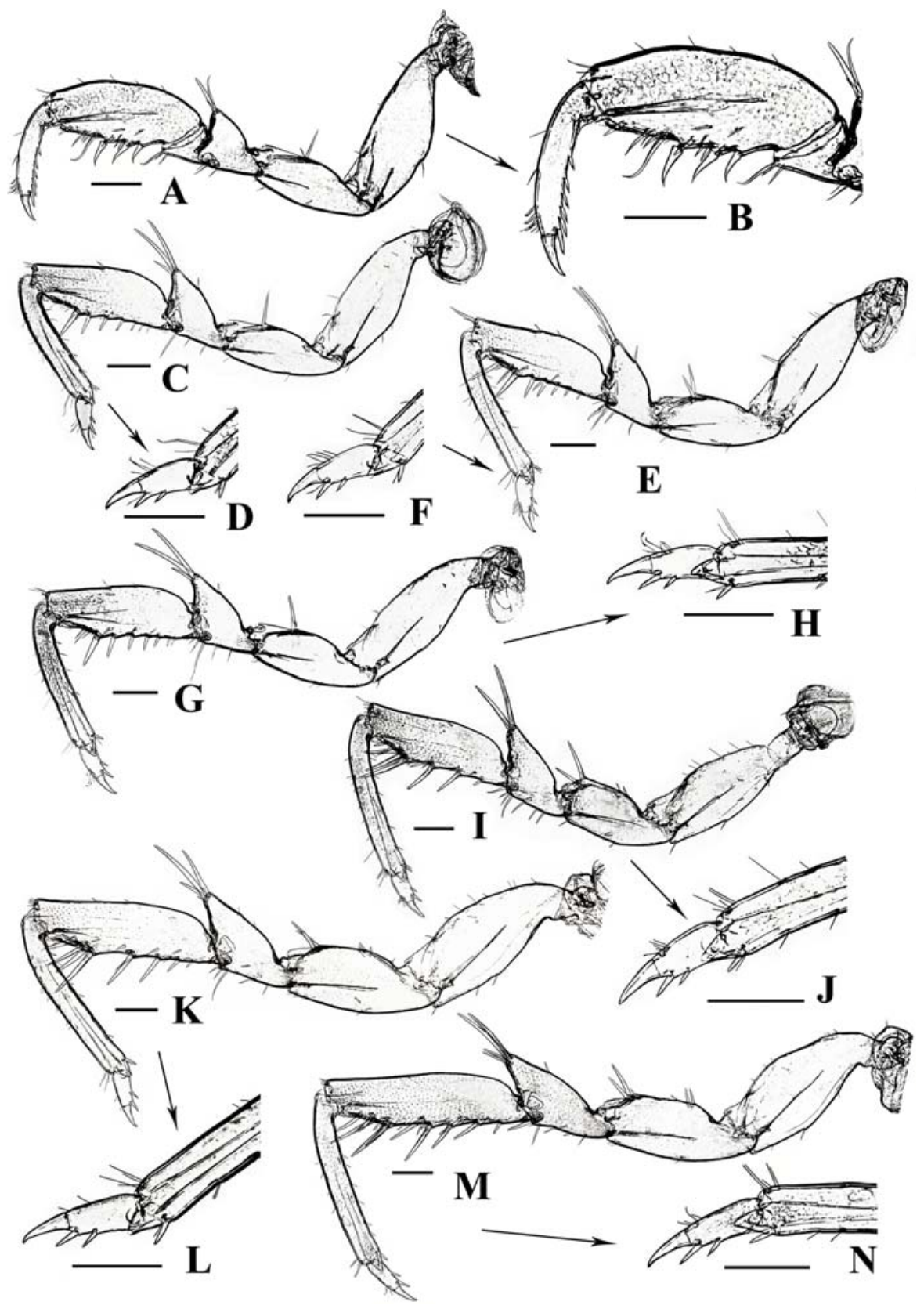

Fig. 7. Proasellus irystonicus sp.n. Holotype $\left(\mathrm{O}^{\top}\right)$ from a stream in an abandoned mine near the settlement of Sadon: A — pereopod I; B - dactylus of PI; C - pereopod II; D — dactylus of PII; E - pereopod III; F - dactylus of PIII; G - pereopod IV; $\mathrm{H}$ - dactylus of PIV; I - pereopod V; J - dactylus of PV; K pereopod VI; L - dactylus of PVI; M - pereopod VII; N — dactylus of PVII. Scale bars: $0.2 \mathrm{~mm}$.

Рис. 7. Proasellus irystonicus sp.n. Голотип $\left(\mathrm{O}^{7}\right)$ из ручья в заброшенной шахте близ поселка Садон: А - переопод I; В - дактилус переопода I; C - переопод II; D - дактилус переопода II; E переопод III; F - дактилус переопода III; G — переопод IV; H - дактилус переопода IV; I — переопод V; J — дактилус переопода V; K — переопод VI; L — дактилус переопода VI; M — переопод VII; N - дактилус переопода VII. Масштабная линейка: 0,2 мм. 

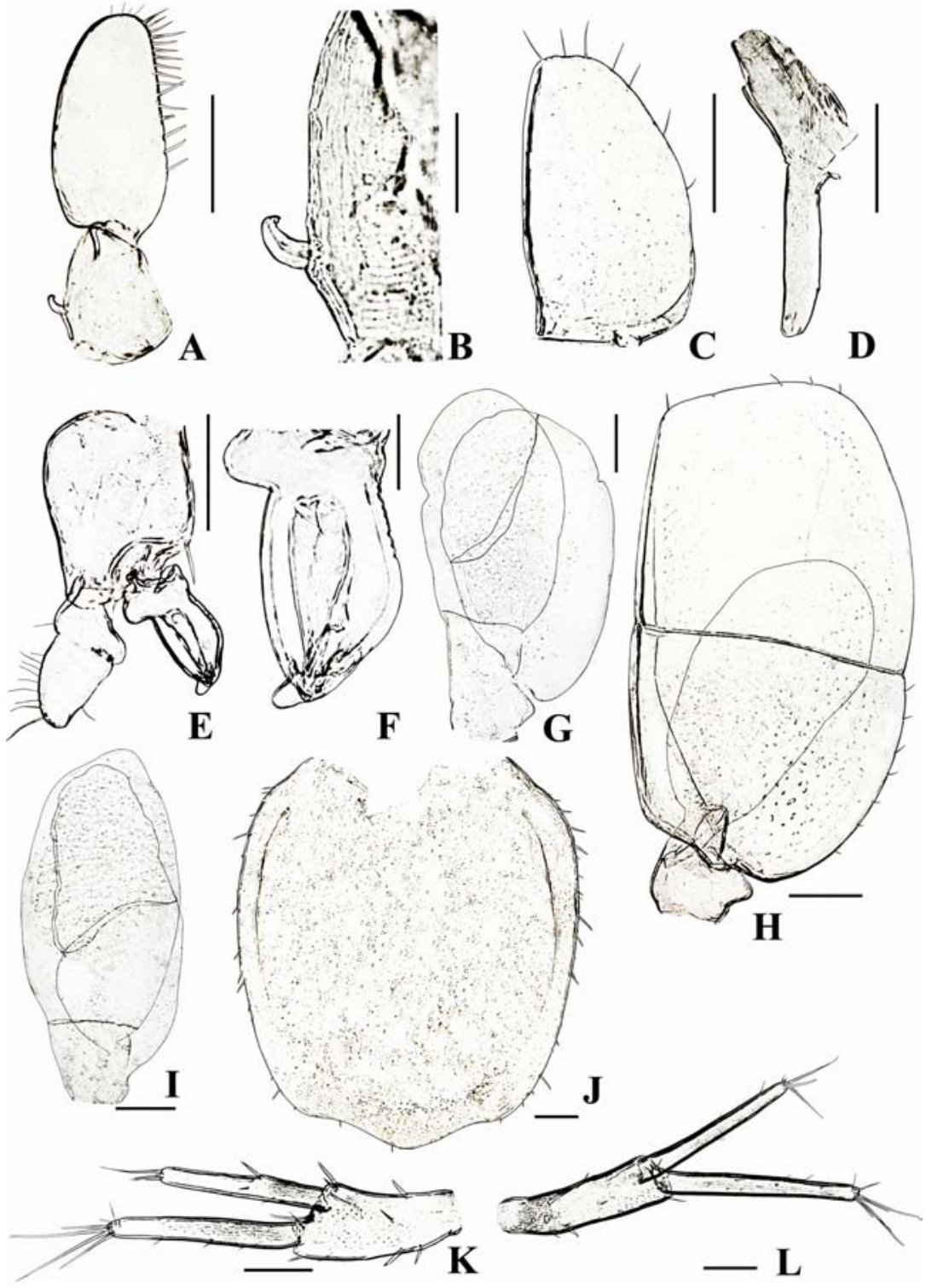

Fig. 8. Proasellus irystonicus sp.n. Holotype $\left(\odot^{7}\right)$ and paratype $(+)$ from a stream in an abandoned mine near the settlement of Sadon: A - pleopod I ( $\mathrm{O}^{7}$ holotype); B - retinacula on medial margin of pleopod I protopodite; $\mathrm{C}$ - pleopod II ( $\odot$ paratype); D - genital papilla ( $\sigma^{7}$ holotype); E — pleopod II ( $\sigma^{7}$ holotype); $\mathrm{F}$ - endopodite of pleopod II ( $\sigma^{7}$ holotype); $\mathrm{G}$ - pleopod IV ( $\sigma^{7}$ holotype); H - pleopod III ( $\sigma^{7}$ holotype); $\mathrm{I}$ - pleopod V ( $\sigma^{7}$ holotype); J — pleotelson ( $\sigma^{7}$ holotype); K — uropod (+ paratype); L — uropod ( $\sigma^{7}$ holotype). Scale bars: A, C-E, G-I - $0.1 \mathrm{~mm}$; J-L $-0.1 \mathrm{~mm}$; B, F $-0.025 \mathrm{~mm}$.

Рис. 8. Proasellus irystonicus sp.n. Голотип $\left(\mathrm{O}^{7}\right)$ и паратип (+) из ручья в заброшенной шахте близ поселка Садон: А — плеопод I (голотип О $\mathrm{O}^{7}$; В — ретинакула на медиальной поверхности протоподита

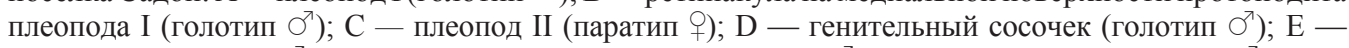

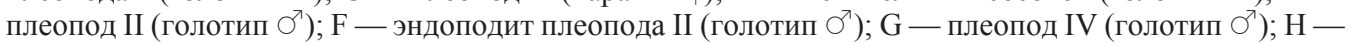

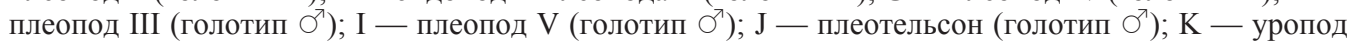
(паратип +); $\mathrm{L}-$ уропод (голотип $\left.\mathrm{O}^{7}\right)$. Масштабная линейка: $\mathrm{A}, \mathrm{C}-\mathrm{E}, \mathrm{G}-\mathrm{I}-0,1$ мм; J-L $-0,1$ мм; $\mathrm{B}, \mathrm{F}-0,025$ мм. 

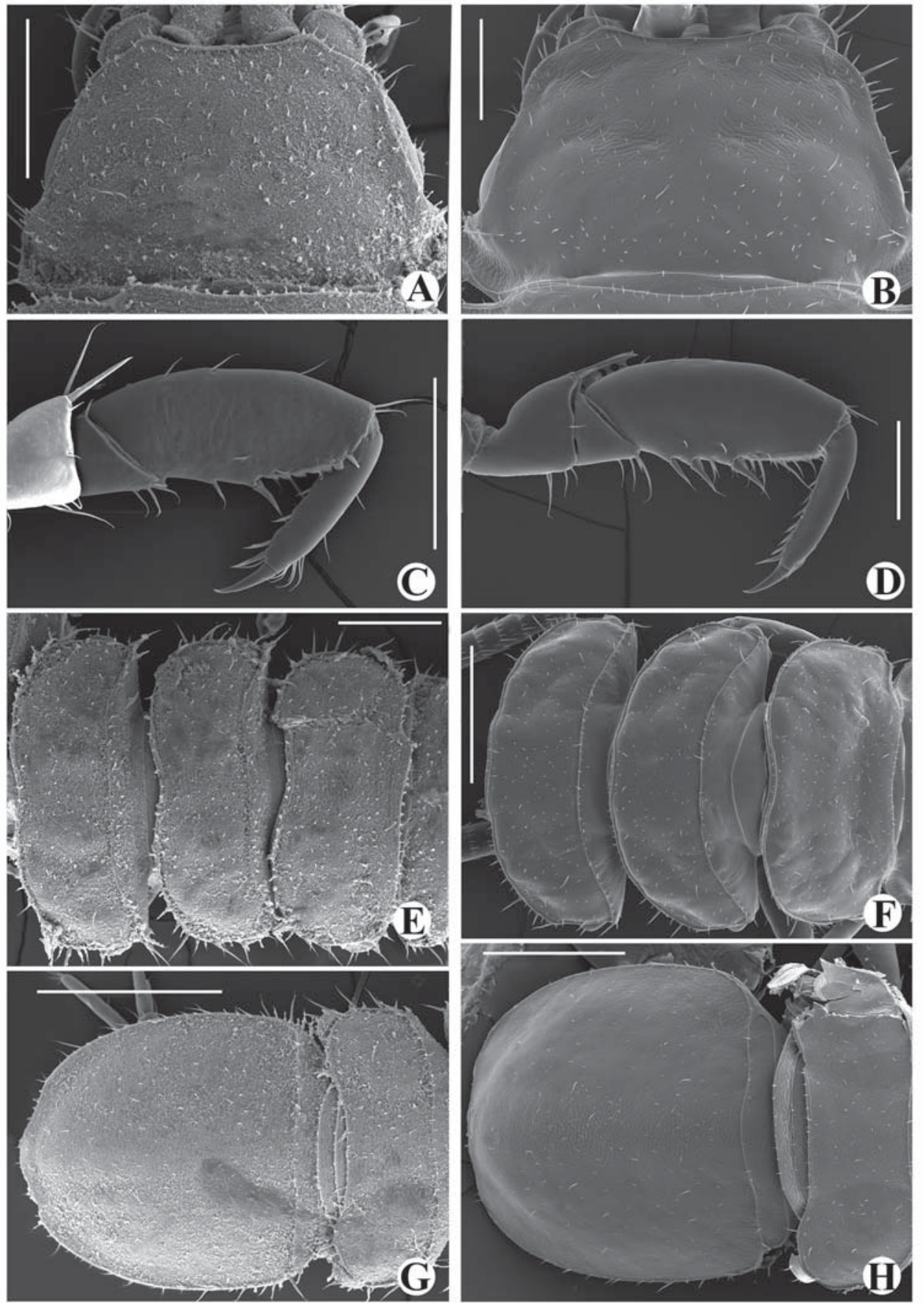

Fig. 9. Proasellus uallagirus sp.n., O paratype (A, C, E, G) and Proasellus irystonicus sp.n., O' paratype (B, D, F, H): A, B - head; C, D - distal part of pereopod I with a dactylus; E, F - pereonites I-III; G, H pleotelson. Scale bars: A-D $-0.25 \mathrm{~mm}$; E-H $-0.5 \mathrm{~mm}$.

Pис. 9. Proasellus uallagirus sp.n., паратип О (A, C, E, G) и Proasellus irystonicus sp.n., паратип О (B, D, F, H): A, В - голова; C, D - дистальная часть переопода I с дактилусом; E, F - переониты I-III; $\mathrm{G}, \mathrm{H}$ - плеотельсон. Масштабная линейка: A-D - 0,25 мм; E-H - 0,5 мм. 
largely covered by posterior margin of pereonite VII. Pleotelson (Figs 8J; 9H) rounded, suboval, its length 1.1-1.2 times of its width, terminal edge bisinuate with obtusely triangular median prominence (Figs 8J; 9H). Lateral margins with few (six or seven) short stout spiniform setae, zero to two shorter setae placed between two longer ones. Terminal edge with few short setae, subterminal margin with scarce short setae. Dorsal surface covered with numerous short delicate setae.

Antenna I (Fig. 6B, C) length $16 \%$ of body length, with 3 peduncular articles. First article robust with straight superior (longer) and curved inferior (shorter) margin, other two articles cylindrical. First and second article subequal in length, third article 1.4 times shorter as each of them. Longest setae on articles I and II about 0.3 as articles in length. Flagellum (Fig. 6C) of nine (in holotype) or eight to twelve (in paratypes) articles, usually from IV to IX articles with one aesthetasc each. Proximal aesthetascs mainly as long as their parallel articles.

Antenna II length (Fig. 6A) $82 \%$ of body length, with six peduncular and 49 flagellar (in holotype) or 36-54 (in paratypes) articles. Sixth peduncular article 1.6 times as long as fifth, both with long and short setae on superior margins. Flagellum length $80 \%$ of antenna II length.

Labrum (Fig. 6E) trapezoidal, with fine simple setae at rounded apex, epistome tapering, with fine setae along margin.

Labium (Fig. 6D) wide, subquadrate, divided almost to half of length.

Mandibulae robust (Fig. 6H, I, J). Pars molaris (molar process) U-shaped, with toothed margin and wrinkled crushing surface. Pars incisiva (incisor) formed by four blunt cusps arranged in semi-circle (Fig. 6H). Left lacinia mobilis with five cusps, spine row of 12-14 biserrate setae (Fig. 6I), right mandible without lacinia mobilis (Fig. 6J). Palp of three articles. First and second article subequal as long. First article narrow, with one or two simple setae on extero-subapical margin. Second article with one or two simple setae and about 13-15 robust long and short biserrate setae along external margin. Third article length 0.63 times of sec- ond, with row of about 13-15 robust biserrate setae along external margin.

Maxillula (Fig. 6G) with inner plate with five apical pappose setae; outer plate with 13 dentate robust setae and a single simple seta subapically on lateral margin.

Maxilla (Fig. 6F) with inner plate longer than outer plate, rounded sub-triangular, with longer row of 16-20 serrate robust setae, shorter row of 9-10 bifid setae laterally and apically, and with oblique row of 25-30 simple setae; lateral and middle plates with 19-23 and 13 striated setae, respectively.

Maxilliped (Fig. 6K) endite distal margin with about 17-20 biserrate robust setae and long simple setae. Mesial margin with about 23-25 biserrate setae, distomesial margin with setulose fringe and four to six coupling hooks, lateral margin with dense setulose fringe. Palp of five articles. First article short, with a single short seta apically on outer margin, second about three times as long as first, subtrapezoidal, with row of about 15 long medially directed simple setae on inner margin and two or three short setae on outer margin. Third article length $70 \%$ of second article length, less broad, with one or two short setae on outer margin and row of about eight to ten setae on inner margin. Fourth article 1.6 times as long as third, slender, with row of three or four and about 12-14 slender setae along outer and inner margin, respectively. Fifth article length $58 \%$ of fourth article length, ovoid, fringed with 13 slender setae, with a single stiff simple apical seta. Epipodite subrectangular, lateral margin fringed with about six stout pointed and four short thin setae.

With exception of first pair, seven pairs of pereopods ambulatory and similar in construction, increasing in length towards posterior pairs.

Pereopod I (Figs 7A, B; 9D) with short oval articles, its length $30 \%$ of body length, length relation of articles from basis to dactylus: 1 : $0.70: 0.37: 0.18: 0.92: 0.70$, unguis length $23 \%$ of dactylus length. Propodus I elongate, oval, up to 2.4 times as long as wide, inferior margin without proximal apophysa, straight or weakly convex, armed with three large robust 
spiniform setae and three or four small spiniform setae. Mesial surface with two or three short simple setae. Dactylus I (Figs 7B; 9D) about 1.3 times as short as propodus, with six short robust setae on inferior margin and five or six simple setae on superior margin.

Pereopod II (Fig. 7C, D) with long slender articles, its length $39 \%$ of body length, length relation of articles from basis to dactylus: 1 : $0.71: 0.40: 0.90: 0.825: 0.33$, unguis length $42 \%$ of dactylus length. Carpus II inferior margin with row of seven robust setae. Propodus II inferior margin with row of five or six spiniform setae, mesial surface with one or two simple setae, inferodistal corner with a single stiff acute robust seta, superior margin and submarginal surface with 10-14 simple setae. Dactylus II (Fig. 7D) inferior margin with two robust stiff setae, superior margin distally with three simple setae.

Pereopod III (Fig. 7E, F) with long slender articles, its length $40 \%$ of body length, length relation of articles from basis to dactylus: 1 : $0.69: 0.40: 0.88: 0.92: 0.36$, unguis length $35 \%$ of dactylus length. Carpus III inferior margin with row of 10 long and short robust setae. Propodus III inferior margin with row of six or seven simple setae, mesial surface with one or two simple setae, inferodistal corner with a single stiff acute robust seta, superior margin and submarginal surface with six or seven simple setae. Dactylus III (Fig. 7F) inferior margin with two robust stiff setae, superior margin distally with five simple setae.

Pereopod IV (Fig. 7G, H) with long slender articles, its length $42 \%$ of body length, length relation of articles from basis to dactylus: 1 : $0.75: 0.41: 0.92: 0.92: 0.33$, unguis length $39 \%$ of dactylus length. Carpus IV inferior margin with row of eight robust setae, mesial surface with two or three short robust setae. Propodus IV inferior margin with row of three or four simple or short stout setae, mesial surface with one or two simple setae, inferodistal corner with a single stiff acute robust seta, superior margin and submarginal surface with eight or ten simple setae. Dactylus IV (Fig. 7H) inferior margin with two robust stiff setae, supe- rior margin distally with five simple setae.

Pereopod V (Fig. 7I, J) with long slender articles, its length $45 \%$ of body length, length relation of articles from basis to dactylus: 1 : $0.68: 0.49: 1.00: 1.05: 0.34$, unguis length $39 \%$ of dactylus length. Carpus V inferior margin with row of seven long robust setae, mesial surface with two short robust setae. Propodus V inferior margin with row of five simple setae, mesial surface with one or two simple setae, inferodistal corner with a single stiff acute robust seta, superior margin and submarginal surface with seven to eight simple setae. Dactylus $\mathrm{V}$ (Fig. 7J) inferior margin with two robust stiff setae, superior margin distally with four simple setae.

Pereopod VI (Fig. 7K, L) with long slender articles, its length $47 \%$ of body length, length relation of articles from basis to dactylus: 1 : $0.81: 0.49: 1.07: 1.01: 0.34$, unguis length $40 \%$ of dactylus length. Carpus VI inferior margin with row of eight robust setae, mesial surface with three or four short simple of robust setae. Propodus VI inferior margin with row of six simple or robust setae, mesial surface with one or two simple setae, inferodistal corner with a single stiff acute robust seta, superior margin and submarginal surface with seven or eight simple setae. Dactylus VI (Fig. 7L) inferior margin with two robust stiff setae, superior margin distally with three simple setae.

Pereopod VII (Fig. 7M, N) with long slender articles, its length $49 \%$ of body length, length relations of articles from basis to dactylus: 1 : $0.80: 0.55: 1.13: 1.02: 0.32$, unguis length $40 \%$ of dactylus length. Carpus VII inferior margin with row of 11 long robust and three or four short simple setae, mesial surface without setae. Propodus VII inferior margin with row of six simple setae, mesial surface with two or three short robust setae, inferodistal corner with a single stiff acute robust seta, superior margin and submarginal surface with six or seven simple setae. Dactylus VII (Fig. 7N) inferior margin with two robust stiff setae, superior margin distally with four simple setae.

Genital papillae (Fig. 8D) thin, cylindrical, straight. 
Pleopod I (Fig. 8A, B) with protopodite subtrapezoidal, 1.30 times as long as wide, retinacula on medial margin consisting of a single hook (Fig. 8B). Exopodite elongated ovoid, its width $53 \%$ of its length, with 16 robust setae on lateral margin and four simple setae on terminal margin, without concavity on lateral margin.

Pleopod II (Fig. 8E, F) with protopodite subrectangular, its width $76 \%$ of its length. Anteromesial corner with 1 simple seta. Exopodite suboval, elongated, 1.9 times as long as wide. Distal article rounded, with eight lateral simple setae and a single mesial simple seta. Proximal segment of exopodite with a single simple seta. Endopodite elongated, its width $45 \%$ of its length, subequal of protopodite in length, with distinct basal apophysis, elongated distal apophysis and with weakly expressed goulot without lips (Fig. 8F).

Pleopod II of female (Fig. 8C) subtriangular, about 1.7 times as long as wide, with seven short marginal simple setae.

Pleopod III (Fig. 8H) with exopodite subrectangular, about 1.7 times as long as wide, with almost straight medial margin. Lateral and terminal margins with 11-12 short simple setae. Endopodite about 1.7 times shorter than exopodite.

Pleopod IV (Fig. 8G) with exopodite broadly ovoid, about 1.62 times as long as wide, lateral margins without setae. Linea transversalis well defined, linea conjungens weakly defined. Endopodite suboval, about 1.1 times longer than exopodite.

Pleopod V (Fig. 8I) with exopodite ovoid, elongated, two times as long as wide, lateral margins without setae. Distal margin rounded. Endopodite suboval, its length $94 \%$ of exopodite length.

Uropods (Fig. 8K, L) different in males and females.

Male uropods (Fig. 8L): with long slender articles, as long as $45 \%$ of pleotelson. Proto-, endo- and exopodite length relation: $1: 0.96$ : 1.11 , respectively. Basis with two or three stout spiniform and simple setae on inner and outer margins each and with distal group of three or four simple setae. Exopodite with two to five short simple setae on inner and outer margins each and with terminal group of long simple setae, longest seta length $35 \%$ of exopodite length. Endopodite with two to four short simple setae on inner and outer margins each and with terminal group of long simple setae, longest seta length $36 \%$ of exopodite length.

Female uropods (Fig. 8K): with short robust articles, as long as $41 \%$ of pleotelson. Proto-, endo- and exopodite length relation: $1: 1.09$ : 1.24 , respectively. Basis with three or four stout spiniform setae on inner and outer margins and with distal group of three or four simple setae. Exopodite with one to three short simple setae on inner and outer margins each and with terminal group of long simple setae, longest seta with length $57 \%$ of exopodite length. Endopodite with two or three short simple or spiniform setae on inner and outer margins each and with terminal group of long simple setae, longest seta length $37 \%$ of exopodite length.

BODY SIZE. The largest collected female had bl. $6.5 \mathrm{~mm}$; the largest male had bl. $5.8 \mathrm{~mm}$.

TAXONOMIC REMARKS.

The species can be most easily separated from Proasellus infirmus, by: 1) a single coupling hook in retinacula of pleopod I (vs two hooks, see Birstein, 1936, fig. 7); 2) lack of eyes, white depigmented body (vs eyes from three facetes, pigmented body, "brighter than Asellus aquaticus", see Birstein, 1936, p. 237 and Birstein, 1951, p. 85 and fig. 112); 3) lack of long plumose setae on pleopodes II (vs setae on pleopodes II long plumose exceed half of their length, see Birstein, 1936, figs 8, 9).

The species can be easily separated from $P$. linearis, by: 1) significantly larger endopodites of pleopodes III-V (ratio exopodite/endopodite of pleopodes III-V is $1.7,1.1,1.0$ vs 3.0, 1.9, 1.4, respectively, see Birstein, 1967, fig. 1); 2) inferior margin of dactylus of pereopodes IIVII with two robust stiff setae (vs a single robust stiff seta, see Birstein, 1967, fig. 1).

The species can be most easily separated from $P$. ljovuschkini, by: 1) a single coupling hook in retinacula of pleopod I (vs two hooks, see Birstein, 1967, fig. 2); 2) lack of setae on 
mesial surface of pleopodes III and pleopodes II in female (vs prominent setae, see Birstein, 1967, fig. 2); 3) inferior margin of pereopodes II-VII with two robust stiff setae (vs a single robust stiff setae, see Birstein, 1967, fig. 2).

The species can be easily separated from $P$. similis, by: 1) a single coupling hook in retinacula of pleopod I (vs two hooks, see Birstein, 1967, fig. 3); 2) flagellum of antenna I of eight to twelve articles (vs four articles, see Birstein, 1967, fig. 3); 3) rami of uropod almost parallel (vs arranged at angle of almost $80^{\circ}$, see Birstein, 1967, fig. 3); 4) pleopod IV wide, its exopodite about 1.7 times as long as wide, shorter than endopodite, without lateral seta (vs pleopod IV narrow, its exopodite about 2.20 times as long as wide, longer than endopodite, with a single lateral seta, see Birstein, 1967, fig. 3).

The species can be most easily separated from P. uallagirus sp.n., by: 1) inferior margin of dactylus of pereopodes II-VII with two robust stiff setae (vs a single seta, see Figs 7 and 4 , respectively); 2) inferior margin of dactylus of pereopodes I with six robust stiff setae (vs three or four setae, see Figs 7B and 4B, respectively); 3 ) inferior margin of propodus of pereopodes I with three long robust stiff setae (vs a single seta, see Figs 7B and 4B, respectively).

DISTRIBUTION AND ECOLOGY. Currently known as strictly endemic species from a stream in an abandoned mine near the settlement of Sadon ( $\left.42^{\circ} 50^{\prime} 40.28^{\prime \prime} \mathrm{N}, 44^{\circ} 01^{\prime} 16.77^{\prime \prime} \mathrm{E}\right)$. The species was found together with the following spring-dwelling invertebrates: Gammarus cf. pulex (Linnaeus, 1758) (Amphipoda: Gammaridae), Niphargus sp. (Amphipoda: Niphargidae) and Plectrocnemia latissima Martynov, 1913 (Trichoptera: Polycentropodidae).

\section{Discussion}

To date, the species described here are the only Proasellus representatives in the Terek River basin and North Caucasus. Geographically, the closest species is $P$. infirmus reported from springs in the Lower Gumista River (central Abkhazia). But morphologically, this epigean isopod with eyes and pigmented body
(Birstein, 1967) drastically differs from the both species described above.

Both species are distributed locally. Like other stygobionts, they apparently cannot spread to large distances (Lefébure et al., 2007; Foulquier et al., 2008; Trontelj et al., 2009). Thus, we can suggest that these species are endemic to the Ardon Gorge region.

Molecular studies on the North-Caucasian amphipods of the genus Niphargus revealed their relict origin, and the earlier suggested ideas of a postglacial recolonization of the Caucasian groundwaters were not confirmed (Marin, Palatov, 2021). The North Caucasian Proasellus species seem to be also the relics that found a presumable refuge in hypogean biotopes during the glaciation, i. e. they descended from some extinct epigeic ancestors lived on this territory (in the interglacial, or before glaciations?). Probably, the ranges of Proasellus, as well as Niphargus, were continuous, but a lot of populations disappeared due to the dramatic Pleistocene climate changes and glaciation (e.g., Popov et al., 2006). Special search of the stygobiotic crustaceans in Kabardino-Balkaria and Karachaevo-Cherkessia (Cherek and Teberda Rivers valleys) was not successful (Palatov, Chertoprud, 2020). There is probably a series of ancient refugia in the North Caucasus and area of foothills of North Ossetia is one of them. The fauna of such refugia obviously needs special habitat protection.

Acknowledgements. The study is supported by the Russian Foundation for Basic Research (RFBR) (grant No. 20-04-00803_A). The authors are sending special thanks to $\bar{Y}$.E. Komarov (North Ossetia Nature Reserve) for the help during the collection and R.A. Rakitov (Paleontological Institute, Russian Academy of Sciences) for the help with obtaining SEM images.

\section{References}

Birstein J.A. 1936. [On the Waterlouses of the Caucasus] // Sbornik Trudov Zoologicheskogo Muzeya MGU. Vol.3. P.235-242 [in Russian].

Birstein J.A. 1951. [Freshwater Isopods (Asellota)] // Fauna SSSR. Rakoobraznye. Vol.7. Pt.5. Moscow: AN SSSR Publ. 144 pp. [In Russian] 
Birstein J.A. 1967. [Subterranean Waterlouses (Crustacea: Isopoda: Asellota) of Transcaucasia] // Zoologicheskii Zhurnal. Vol.46. No.6. P.856-865 [in Russian].

Capderrey C., Kaufmann B., Jean P., Malard F., KonecnyDupré L., Lefebure T., Douady Ch.J. 2013. Microsatellite development and first population size estimates for the groundwater isopod Proasellus walteri // PLoS ONE. Vol.8. No.9. e76213. doi:10.1371/journal. pone. 0076213

Foulquier A., Malard F., Lefébure T., Douady Ch.J., Gibert J. 2008. The imprint of quaternary glaciers on the present-day distribution of the obligate groundwater amphipod Niphargus virei (Niphargidae) // Journal of Biogeography. Vol.35. No.3. P.552-564. https://doi. org/10.1111/j.1365-2699.2007.01795.x

Golovatch S.I., Palatov D.M., Turbanov I.S., Kniss V.A., Gazaryan S., Snit'ko V.P., Decu V., Juberthie Ch., Nazareanu G. 2018. Subterranean biota of the European part of Russia: A review // Invertebrate Zoology. Vol.15. No.2. P.153-213. https://doi.org/10.15298/ invertzool.15.2.01

Lefébure T., Douady Ch.J., Malard F., Gibert J. 2007. Testing dispersal and cryptic diversity in a widely distributed groundwater amphipod (Niphargus rhenorhodanensis) // Molecular Phylogenetics and Evolution. Vol.42. No.3. P.676-686. https://doi.org/ 10.1016/j.ympev.2006.08.020

Marin I., Palatov D. 2019. A new species of the genus Niphargus (Crustacea: Amphipoda: Niphargidae) from the south-western part of the North Caucasus // Zoology in the Middle East. Vol.65. No.4. P.336-346. https://doi.org/10.1080/09397140.2019.1663907

Marin I., Palatov D. 2021. Cryptic refugee on the northern slope of the Greater Caucasian Ridge: Discovery of Niphargus (Crustacea: Amphipoda: Niphargidae) in the North Ossetia - Alania, North Caucasus, separated from its relatives in the late Miocene // Zoologischer Anzeiger. Vol.292. P.163-183. https://doi.org/ 10.1016/j.jcz.2021.03.002
Morvan C., Malard F., Paradis E., Lefebure T., KonecnyDupre L., Douady Ch.J. 2013. Timetree of Aselloidea Reveals Species Diversification Dynamics in Groundwater // Systematic Biology. Vol.62. No.4. P.512522. https://doi.org/10.1093/sysbio/syt015

Palatov D.M., Chertoprud M.V. 2020. Macrozoobenthos communities of springs and streams of the Eastern Circum-Pontic region// Inland Water Biology. Vol.13. No.4. P.583-596. https://doi.org/10.1134/ S1995082920040070

Palatov D.M., Sokolova A.M. 2019. Stygobiotic faunal elements in spring assemblages of West Transcaucasia // Ecosystem Transformation. Vol.2. No.1. P.1-9. https://doi.org/10.23859/estr-180128

Popov S.V., Shcherba I.G., Ilyina L.B., Nevesskaya L.A., Paramonova N.P., Khondkarian S.O., Magyar I. 2006. Late Miocene to Pliocene paleogeography of the Paratethys and its relation to the Mediterranean // Palaeogeography, Palaeoclimatology, Palaeoecology Vol.238. No.1-4. P.91-106. https://doi.org/10.1016/ j.palaeo.2006.03.020.

Trontelj P., Douady Ch.J., Fišer C., Gibert J., Gorički Š., Lefébure T., Sket B., Zakšek V. 2009. A molecular test for cryptic diversity in ground water: how large are the ranges of macro-stygobionts? // Freshwater Biology. Vol.54. No.4.P.727-744.https://doi.org/10.1111/ j.1365-2427.2007.01877.x

Turbanov I.S., Palatov D.M., Golovatch S.I. 2016. The state of the art of biospeleology in Russia and other countries of the former Soviet Union: a review of the cave (endogean) invertebrate fauna. 1. Introduction - Crustacea // Entomological Review. Vol.96. No.7. P.926-963. S0013873816070162

Verovnik R., Prevorčnik S., Jugovic J. 2009. Description of a neotype for Asellus aquaticus Linné, 1758 (Crustacea: Isopoda: Asellidae), with description of a new subterranean Asellus species from Europe // Zoologischer Anzeiger. Vol.248. No.2. P.101-118. https:// doi.org/10.1016/j.jcz.2009.03.001

Responsible editor A.A. Kotov 